\title{
CHARACTERIZATION OF BIO-OIL FROM PALM KERNEL SHELL PYROLYSIS
}

\author{
R. Ahmad", N. Hamidin, U.F.M. Ali and C.Z.A. Abidin \\ School of Environmental Engineering, University Malaysia Perlis, \\ 02600 Arau, Perlis, Malaysia. \\ *Email: razi@unimap.edu.my \\ Phone: +6049798626; Fax: +6049798636
}

\begin{abstract}
Pyrolysis of palm kernel shell in a fixed-bed reactor was studied in this paper. The objectives were to investigate the effect of pyrolysis temperature and particle size on the products yield and to characterize the bio-oil product. In order to get the optimum pyrolysis parameters on bio-oil yield, temperatures of $350,400,450,500$ and $550{ }^{\circ} \mathrm{C}$ and particle sizes of $212-300 \mu \mathrm{m}, 300-600 \mu \mathrm{m}, 600 \mu \mathrm{m}-1.18 \mathrm{~mm}$ and $1.18-2.36 \mathrm{~mm}$ under a heating rate of $50{ }^{\circ} \mathrm{C} \mathrm{min}^{-1}$ were investigated. The maximum bio-oil yield was $38.40 \%$ at $450{ }^{\circ} \mathrm{C}$ with a heating rate of $50{ }^{\circ} \mathrm{C} \mathrm{min}^{-1}$ and a nitrogen sweep gas flow rate of $50 \mathrm{ml} \mathrm{min}{ }^{-1}$. The bio-oil products were analysed by Fourier transform infra-red spectroscopy (FTIR) and gas chromatography-mass spectroscopy (GCMS). The FTIR analysis showed that the bio-oil was dominated by oxygenated species. The phenol, phenol, 2-methoxy- and furfural that were identified by GCMS analysis are highly suitable for extraction from the bio-oil as value-added chemicals. The highly oxygenated oils need to be upgraded in order to be used in other applications such as transportation fuels.
\end{abstract}

Keywords: Biomass; renewable energy; pyrolysis; palm kernel shell; bio-oil; char.

\section{INTRODUCTION}

Renewable energy can be considered as an alternative to conventional energy sources $[1,2]$. It is capable of assuring secure and sustainable development while energy consumption is increasing and fossil fuels are limited, with a growing population and economic developments [3-6]. Currently, biomass is highlighted as a promising renewable energy source due to environmental problems caused by the combustion of fossil fuels and the shortage of fossil fuels expected in the future. Fast pyrolysis has potential prospects for the thermo-chemical conversion of lignocellulosic biomass into liquid fuels because of its higher yield and quality of liquid oil compared to other techniques [7]. Pyrolysis is the thermal conversion of organics in the absence of oxygen. In this biomass, pyrolysis commonly refers to lower temperatures in a $300{ }^{\circ} \mathrm{C}-800{ }^{\circ} \mathrm{C}$ thermal process producing liquids (bio-oil), solid (char) and gases. Pyrolysis is one of the most recent renewable energy processes and promises high yields of liquid $(75 \%)$ with a minimum of gas and bio-char under a controlled environment [8-11]. However, among the thermochemical conversion methods, pyrolysis is the most suitable method to produce bio-oil as the main product, compared to gasification and combustion. In the pyrolysis process, when the components are quickly quenched, the volatile components condense to bio-oil. The bio-oil can be substituted for fuel oil in many static 
applications including boilers, combustion engines and turbines for the generation of electricity, or can be subjected to further treatment and processes to produce secondary products such as higher value and quality fuel or chemical products [12]. Biomass utilization gives the possibility of generating value-added products such as chemicals or activated carbons, which means an attractive economic and technological solution [1316]. The major contributor of biomass in Malaysia that has the potential to generate energy is the palm oil industry, where most of the wastes are empty fruit bunches (EFB), mesocarp fibre, palm kernel shells (PKS), and palm kernel cake (residue). Among the palm oil wastes, PKS has a great potential as a source of biomass to develop renewable energy sources. Since the PKS produced from palm oil mills is abundant, cheap and does not require significant effort to collect, it is currently used as a low energy efficiency fuel for boilers [17]. Meanwhile, converting palm kernel shell to biooil under a thermal process provides a greater benefit to use as biomass energy to replace fossil fuels, and it minimizes the disposal problems associated with the generation of agricultural by-products. In this study, the pyrolysis of palm kernel shell was conducted in a fixed-bed reactor. The effects of the pyrolysis parameters on the product yield were investigated and bio-oil product characterization was explored.

\section{MATERIAL AND METHOD}

\section{Material}

The biomass used for the pyrolysis process was palm kernel shell (PKS). The PKS was collected from Malpom Industries Sdn Bhd, Jalan Bukit Changkat, Nibong Tebal, Pulau Pinang. PKS is the shell material left after the nut has been removed after crushing in the palm oil mill. It is dried in the oven at a temperature of $105{ }^{\circ} \mathrm{C}$ for 2 hours to remove the moisture content. By using a crusher, the palm kernel shells are reduced to a small size. The palm kernel shells are sieved using a sieve shaker to separate the particle sizes needed. The palm kernel shell collected had particle sizes of $212-300 \mu \mathrm{m}, 300-600 \mu \mathrm{m}$, $600 \mu \mathrm{m}-1.18 \mathrm{~mm}$ and $1.18-2.36 \mathrm{~mm}$ in diameter. The proximate analysis and ultimate analysis are shown in Table 1.

Table 1. Proximate and ultimate analysis of palm kernel shell.

\begin{tabular}{lclc}
\hline Proximate analysis & $\begin{array}{c}\text { Value } \\
(\text { wt\% })\end{array}$ & Ultimate analysis & $\begin{array}{c}\text { Value } \\
(\mathrm{wt} \%)\end{array}$ \\
\hline Moisture content & 6.33 & Carbon & 44.29 \\
Volatile matter & 62.82 & Hydrogen & 9.01 \\
Fixed carbon & 19.10 & Nitrogen & 2.37 \\
Ash & 11.75 & Sulphur & 1.20 \\
& & Oxygen $^{\mathrm{a}}$ & 43.13 \\
\hline
\end{tabular}

${ }^{\mathrm{a}}$ By difference

\section{Pyrolysis Process}

A fixed bed reactor, R-301 Series Catatest Reactor System, was used for the biomass pyrolysis experiments. The reactor tube was filled with $5 \pm 0.5 \mathrm{~g}$ palm kernel shell with 212-300 $\mu \mathrm{m}, 300-600 \mu \mathrm{m}, 600 \mu \mathrm{m}-1.18 \mathrm{~mm}$ and $1.18-2.36 \mathrm{~mm}$ particle sizes. A heating rate of $50{ }^{\circ} \mathrm{C} / \mathrm{min}$ and a constant flow rate of $\mathrm{N}_{2}$ at $50 \mathrm{ml} / \mathrm{min}$ were used in the pyrolysis experiment in order to achieve an inert atmosphere during pyrolysis. The 
pyrolysis yield results from the various parameters of the pyrolysis process were investigated by identifying the effects of temperature $\left(350{ }^{\circ} \mathrm{C}, 400{ }^{\circ} \mathrm{C}, 450{ }^{\circ} \mathrm{C}, 500{ }^{\circ} \mathrm{C}\right.$ and $\left.550{ }^{\circ} \mathrm{C}\right)$ and the palm kernel shell particle size $(212-300 \mu \mathrm{m}, 300-600 \mu \mathrm{m}, 600 \mu \mathrm{m}-$ $1.18 \mathrm{~mm}$ and $1.18-2.36 \mathrm{~mm}$ ). The char and bio-oil products were weighed to calculate the percentage of the yield. The gas produced was calculated by differences. The bio-oil was analysed using Fourier transform-infrared (FT-IR/FT-NIR Spectrometer Spectrum 400, Perkin Elmer) and gas chromatography mass spectroscopy (GC/MS-GP 2010 Series, Shidmadzu).

\section{RESULTS AND DISCUSSION}

\section{Effect of Temperature and Particle Size on Pyrolysis Product}

Figure 1 shows the effect of temperature on the product yields for temperatures of 350 , $400,450,500$ and $550{ }^{\circ} \mathrm{C}$ with $600 \mu \mathrm{m}-1.18 \mathrm{~m}$ palm kernel shell particle sizes and a heating rate of $50{ }^{\circ} \mathrm{C} / \mathrm{min}$. The optimum temperature was $450{ }^{\circ} \mathrm{C}$, producing the maximum bio-oil yield of $38.40 \%$. The result shows that as the temperature begins to increase from 350 to $450{ }^{\circ} \mathrm{C}$, the bio-oil yield increases to the maximum from 28.90 wt $\%$ to $38.40 \mathrm{wt} \%$. Then, from $450{ }^{\circ} \mathrm{C}$ to $500{ }^{\circ} \mathrm{C}$, the bio-oil yield dropped sharply by about $10.56 \mathrm{wt} \%$, from $39.40 \mathrm{wt} \%$ to $27.84 \mathrm{wt} \%$. The yield remained stable until the final pyrolysis temperature, $550{ }^{\circ} \mathrm{C}$. The bio-oil product decreased at pyrolysis temperatures of 450 to $550{ }^{\circ} \mathrm{C}$ due to the decrease of the organic and specific products and secondary cracking of volatiles at temperatures above $500{ }^{\circ} \mathrm{C}$ [18]. Above this temperature, the bio-oil yield decreased with the conjunction of releasing more gas products due to secondary cracking [19]. It was concluded that the optimum temperature for bio-oil production was $450{ }^{\circ} \mathrm{C}$ in the present experimental conditions.

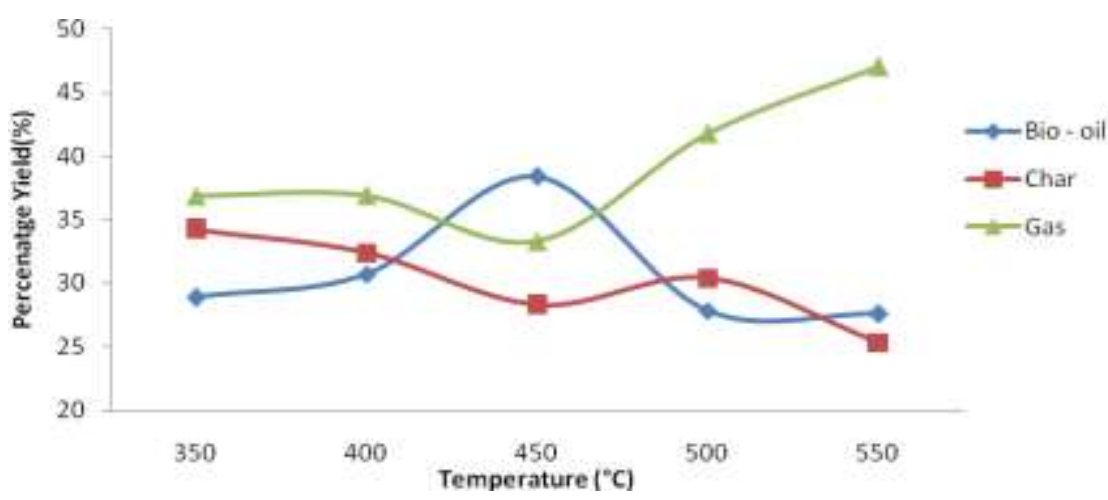

Figure 1. Effect of pyrolysis temperature on product yield.

Figure 2 shows that the maximum bio-oil yield of $38.40 \%$ was obtained with particle sizes of $600 \mu \mathrm{m}-1.18 \mathrm{~mm}$. The smallest particle size of $212-300 \mu \mathrm{m}$ produced the lowest bio-oil yield of $12.53 \%$, with a char yield of $29.06 \%$ and gas yield of $58.41 \%$. Besides that, the largest particle size of $1.18-2.36 \mathrm{~mm}$ produced a bio-oil yield of $30.49 \%$, which was $7.81 \%$ less than the highest bio-oil yield produced. This was due to the fact that the smaller size particles were either overheated or blown too quickly from the reactor before pyrolysis took place, so producing less bio-oil. On the other hand, the larger particle sizes were not heated up sufficiently rapidly, causing 
incomplete pyrolysis and so producing less bio-oil [20]. Another study by Phan et al. [21] on rice straw showed that the oil yield decreased from $52.76 \%$ to $48.52 \%$ as the particle size increased from the range $500 \mu \mathrm{m}-1.00 \mathrm{~mm}$ to the range $1.00-2.00 \mathrm{~mm}$. This is because, when the biomass particle size increases, the distance from the biomass particle's surface to its centre increases, which delays the heat transfer rate from the hot material to cold biomass. Therefore, the bio-oil yield decreases [22].

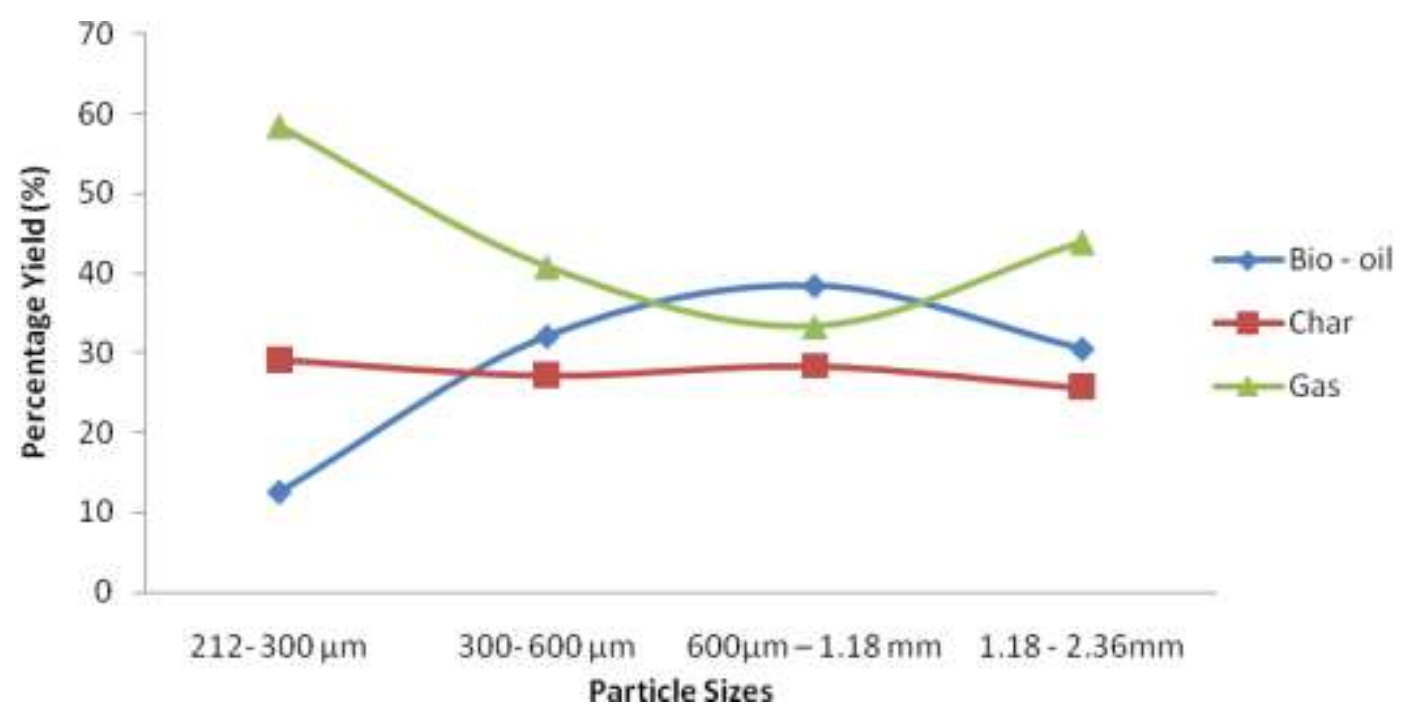

Figure 2. Effect of particle size on product yield.

\section{Bio-oil Characterization}

The Fourier transform infra-red spectroscopy (FT-IR) analysis was conducted on bio-oil obtained from the optimum pyrolysis parameter. The $\mathrm{O}-\mathrm{H}$ stretching vibrations between 3200 and $3600 \mathrm{~cm}^{-1}$ indicate the presence of phenol and alcohols. The $\mathrm{C}-\mathrm{H}$ stretching vibrations between 2800 and $3000 \mathrm{~cm}^{-1}$ and $\mathrm{C}-\mathrm{H}$ deformation vibrations between 1350 and $1465 \mathrm{~cm}^{-1}$ indicate the presence of alkanes. The $\mathrm{C}=\mathrm{O}$ stretching vibrations between $1640 \mathrm{~cm}^{-1}$ and $1780 \mathrm{~cm}^{-1}$ represent the presence of ketones, aldehydes, carboxylic acids and their derivatives. The absorbance peaks between $1580 \mathrm{~cm}^{-1}$ and $1680 \mathrm{~cm}^{-1}$ represent $\mathrm{C}=\mathrm{C}$ stretching vibrations indicative of alkenes and aromatics. Absorptions possibly due to C-O vibrations from carbonyl components (i.e., alcohols, esters, carboxylic acids or ether) occur between $950 \mathrm{~cm}^{-1}$ and $1300 \mathrm{~cm}^{-1}$ of the bio-oil. Absorbance peaks between 650 and $900 \mathrm{~cm}^{-1}$ indicate the possible presence of single, polycyclic and substituted aromatic groups [23]. Table 2 shows the FTIR analysis of the bio-oil.

Gas chromatography-mass spectroscopy (GCMS) analysis as shown in Table 3 was carried out on the optimum parameter of bio-oil yield. The highest values of the peak areas of possible compounds were phenol, phenol, 2-methoxy- and furfural, with $39.52 \%, 7.27 \%$ and $5.20 \%$ respectively. The concentrations of phenol and its derivative were very high, indicating the suitability of the oil to be considered for value-added chemicals. In addition, it is possible to deoxygenate the bio-oil to obtain higher-grade fuel [24]. 
Table 2. FTIR functional group compositions of biomass bio-oil.

\begin{tabular}{|c|c|c|}
\hline $\begin{array}{l}\text { Frequency range } \\
\left(\mathrm{cm}^{-1}\right)\end{array}$ & Group & Class of compound \\
\hline $3200-3600$ & $\mathrm{O}-\mathrm{H}$ stretching & Polymeric $\mathrm{O}-\mathrm{H}$, water impurities \\
\hline $3000-2800$ & $\mathrm{C}-\mathrm{H}$ stretching & Alkanes \\
\hline $1780-1640$ & $\mathrm{C}=\mathrm{O}$ stretching & $\begin{array}{l}\text { Ketones, aldehydes, carboxylic } \\
\text { acids }\end{array}$ \\
\hline $1680-1580$ & $\mathrm{C}=\mathrm{C}$ stretching & Alkenes \\
\hline $1550-1490$ & - NO2 stretching & Nitrogenous compounds \\
\hline $1465-1350$ & $\mathrm{C}-\mathrm{H}$ stretching & Alkanes \\
\hline $950-1300$ & $\mathrm{C}-\mathrm{O}$ stretching & $\begin{array}{l}\text { Primary, secondary and tertiary } \\
\text { alcohol, }\end{array}$ \\
\hline $000-650$ & $\mathrm{O}-\mathrm{H}$ stretching & Phenol, esters, ethers \\
\hline
\end{tabular}

Table 3. Identification and peak areas of chemical compounds in biomass pyrolysis oil.

\begin{tabular}{|c|c|c|c|}
\hline Chemical compounds & $\begin{array}{c}\text { Peak area } \\
(\%)\end{array}$ & Chemical compounds & $\begin{array}{c}\text { Peak area } \\
(\%)\end{array}$ \\
\hline 1-Hydroxy-2-butanone & 1.94 & 1,2-benzonediol & 4.97 \\
\hline Acetic acid, methyl ester & 4.76 & 2-methoxy-5-methylphenol & 1.72 \\
\hline Propylone oxide & 1.49 & $\begin{array}{l}\text { 1-hexadecanone, 1- } \\
\text { cyclopentyl- }\end{array}$ & 1.52 \\
\hline Furfural & 5.20 & 1,2-benzebediol,3-methoxy- & 3.20 \\
\hline 2-propanone, 1-(acetyloxy) & 2.26 & 1,2-benzenediol,3-methyl- & 1.31 \\
\hline $2(5 \mathrm{H})$-furanone & 1.95 & 3-nitropropanoic acid & 1.72 \\
\hline 1-piperidinepropanonitrile & 1.72 & Phenol,2,6-dimethoxy- & 6.76 \\
\hline Phenol & 39.52 & 1,2,3-trimethoxybenzene & 1.71 \\
\hline $\begin{array}{l}\text { 1,2-cyclopentanedione,3- } \\
\text { methyl- }\end{array}$ & 1.98 & Benzoic acid, 4-hydroxy- & 4.22 \\
\hline Phenol, 2-methoxy- & 7.27 & $\begin{array}{l}. \text { beta-D-glucopyranone, } 1,6- \\
\text { anyhydro- }\end{array}$ & 4.78 \\
\hline
\end{tabular}

\section{CONCLUSIONS}

The palm kernel shell was pyrolyzed in a R-301 Catatest Reactor System to obtain the pyrolysis products, which were bio-oil, char and gas. The maximum yield of bio-oil was $38.4 \mathrm{wt} \%$ achieved at a pyrolysis temperature of $450{ }^{\circ} \mathrm{C}$, heating rate of $50{ }^{\circ} \mathrm{C} / \mathrm{min}$ and particle size of $600 \mu \mathrm{m}-1.18 \mathrm{~mm}$. The results showed that the bio-oil was highly oxygenated, containing a high fraction of phenol-based compound. FT-IR analysis showed that the liquid was highly dominated by oxygenated species. Obviously, the highly oxygenated oil needs to be upgraded in order to raise the heating values before it can be used as industrial fuel. Phenol, phenol, 2-methoxy- and furfural were identified by GC-MS analysis and these are very suitable for extraction from the bio-oil for valueadded chemicals. 


\section{ACKNOWLEDGEMENT}

The authors are obliged to the School of Environmental Engineering, Universiti Malaysia Perlis for providing laboratory facilities and financial assistance under project no. RAGS 9018-00069.

\section{REFERENCES}

[1] Omer AM. Built environment: Relating the benefits of renewable energy technologies. International Journal of Automotive and Mechanical Engineering. 2012;5:561-75.

[2] Mat Hassan NN, M. Rus AZ. Acoustic performance of green polymer foam from renewable resources after UV exposure. International Journal of Automotive and Mechanical Engineering. 2014;9:1639-48.

[3] Zhang Q, Chang J, Wang T, Xu Y. Review of biomass pyrolysis oil properties and upgrading research. Energy Conversion and Management. 2007;48:87-92.

[4] Kamil M, Rahman MM, Bakar RA. Performance evaluation of external mixture formation strategy in hydrogen fueled engine. Journal of Mechanical Engineering and Sciences. 2011;1:87-98.

[5] Gharehghani A, Hosseini R, Yusaf T. Investigation of the effect of additives to natural gas on heavy-duty si engine combustion characteristics. Journal of Mechanical Engineering and Sciences. 2013;5:677-87.

[6] Ghobadian B, Najafi G, Nayebi M. A semi-empirical model to predict diesel engine combustion parameters. Journal of Mechanical Engineering and Sciences. 2013;4:373-82.

[7] Bridgwater AV. Review of fast pyrolysis of biomass and product upgrading. Biomass and Bioenergy. 2012;38:68-94.

[8] Sukiran MA, Kheang LS, Bakar NA, May CY. Production and characterization of bio-char from the pyrolysis of empty fruit bunches. American Journal of Applied Sciences. 2011;8:984-8.

[9] Kalyani Radha K, Naga Sarada S, Rajagopal K, Nagesh EL. Performance and emission characteristics of CI engine operated on vegetable oils as alternative fuels. International Journal of Automotive and Mechanical Engineering. 2011;4:414-27.

[10] Mohanamurugan S, Sendilvelan S. Emission and combustion characteristics of different fuel In A HCCI engine. International Journal of Automotive and Mechanical Engineering. 2011;3:279-92.

[11] Nematizade P, Ghobadian B, Najafi G. Investigation of fossil fuels and liquid biofuels blend properties using artificial neural network. International Journal of Automotive and Mechanical Engineering. 2012;5:639-47.

[12] Shuangning X, Weiming Y, Li B. Flash pyrolysis of agricultural residues using a plasma heated laminar entrained flow reactor. Biomass and Bioenergy. 2005;29:135-41.

[13] González J, Román S, Encinar J, Martínez G. Pyrolysis of various biomass residues and char utilization for the production of activated carbons. Journal of Analytical and Applied Pyrolysis. 2009;85:134-41.

[14] Al-Kayiem HH, Md Yunus Y. Drying of empty fruit bunches as wasted biomass by hybrid solar-thermal drying technique. Journal of Mechanical Engineering and Sciences. 2013;5:652-61. 
[15] Noor MM, Wandel AP, Yusaf T. Design and development of MILD combustion burner. Journal of Mechanical Engineering and Sciences. 2013;5:662-76.

[16] Noor MM, Wandel AP, Yusaf T. The simulation of biogas combustion in a mild burner. Journal of Mechanical Engineering and Sciences. 2014;6:995-1013.

[17] Abnisa F, Daud W, Husin W, Sahu J. Utilization possibilities of palm shell as a source of biomass energy in Malaysia by producing bio-oil in pyrolysis process. Biomass and Bioenergy. 2011;35:1863-72.

[18] Uzun BB, Pütün AE, Pütün E. Fast pyrolysis of soybean cake: product yields and compositions. Bioresource Technology. 2006;97:569-76.

[19] Raja SA, Kennedy ZR, Pillai B, Lee C. Flash pyrolysis of jatropha oil cake in electrically heated fluidized bed reactor. Energy. 2010;35:2819-23.

[20] Neves D, Thunman H, Matos A, Tarelho L, Gómez-Barea A. Characterization and prediction of biomass pyrolysis products. Progress in Energy and Combustion Science. 2011;37:611-30.

[21] Phan Binh MQ, Duong Long T, Nguyen Viet D, Tran Trong B, Nguyen My HH, Nguyen Luong H, Nguyen Duc A, Luu Loc C. Evaluation of the production potential of bio-oil from Vietnamese biomass resources by fast pyrolysis. Biomass and Bioenergy. 2014;62;74-81.

[22] Chan WCR, Kelbon M, Krieger-Brockett B. Single-particle biomass pyrolysis: correlations of reaction products with process conditions. Industrial \& Engineering Chemistry Research. 1988;27:2261-75.

[23] Nurul Islam M, Zailani R, Nasir Ani F. Pyrolytic oil from fluidised bed pyrolysis of oil palm shell and itscharacterisation. Renewable Energy. 1999;17:73-84.

[24] Bridgwater A. Production of high grade fuels and chemicals from catalytic pyrolysis of biomass. Catalysis Today. 1996;29:285-95. 